\title{
Original Patterns, Macro Nutrition and Vitamin- A Intake in Wasting Toddlers in Sukarami Health Center Palembang City
}

\author{
${ }^{1 s t}$ Manuntun Rotua \\ Department of Nutrition \\ Politeknik Kesehatan Kemenkes Palembang \\ Palembang, Indonesia \\ Email: manuntun_rotua@yahoo.com
}

\author{
2nd Terati \\ Department of Nutrition \\ Politeknik Kesehatan Kemenkes Palembang \\ Palembang, Indonesia \\ Email: terati_idris@yahoo.co.id
}

Corresponding author: manuntun_rotua@yahoo.com

\begin{abstract}
Wasting is a condition of the body that is thin and so thin that it exceeds -2 Standard Deviation under the median body weight according to height or length. The objective of this research, therefore, was to analyze the original patterns, macro nutrition and vitamin-A intake with wasting toddlers. The focus on this research was on children in Sukarami Health Center. Observational analytical research with a case control approach was used, along with multi stage cluster sampling, involving a total of 60 toddlers. Data was collected through interviews using questionnaires and form recall. Data processing was performed using computer software. The data was then analyzed using a Chi-square test at $\mathbf{0 . 0 5}$ level of significance. The results showed that there was a significant association between parenting $(p=0.025)$, energy intake $(p=0.000)$, protein intake $(p=0.026)$, fat $(p=0.007)$, carbohydrate intake ( $p=0.000$ ) with wasting. There is no significant association between vitamin-A intake with wasting $(p=0.424)$. Therefore, it can be concluded that parenting in macro nutrition intake contributes to the occurrence of wasting in infants.
\end{abstract}

Keywords: parenting, macro nutrition, vitamin-A, wasting toddler.

\section{INRODUCTION}

Wasting is a thin and very thin body that exceeds -2 SD in the median body weight according to height or body length [1]. Causes of malnutrition other than food are due to the availability of food in the household that is not fulfilled, parenting in children and access to health services that are not affordable so that it can cause wasting [2].

The impact of wasting on children is experiencing a decrease in the power of isolation to their environment, an increase in the frequency of crying, lack of interaction with fellow children, less feeling happy, and tends to be apathetic. In the long run, the child will experience cognitive impairment, decreased learning achievement, behavioral disorders, and even an increased risk of death [3]. [3].

According to UNICEF data for 2017, there was 92 million $(13.58 \%)$ under five in the world experienced underweight, 151 million (22\%) under five experienced stunting and 51 million (7.5\%) had children under five wasting. Most of the toddlers in the world were experienced underweight, stunting and wasting comes from the continents of Africa and Asia [4]. [4]. The results of 2017 PSG surveillance data in Indonesia, the prevalence of nutritional status of children under five years old (0-59 months) according to the $\mathrm{BB} / \mathrm{TB}$ index of $9.5 \%$ experienced wasting (2.8\% very thin and $6.7 \%$ thin) [5]. [5]. In South Sumatra Province the prevalence of nutritional status of children under five years old (0-59 months) was $7.8 \%$ having wasting ( $2 \%$ of toddlers very thin and $5.8 \%$ thin). Palembang City Health Office said that in 2017 out of 39 Health Center spread across Palembang City, the nutritional status of wasting with the highest prevalence was found in Boom Baru Health Center which was 12.4 percent, Keramasan Health Center which was $6.4 \%$ and Sukarami Health Center 5.5\% [6]. 
From the data mentioned above, the researchers are interested in conducting research on the pattern of upbringing and intake of macronutrients in toddlers wasting and stunting in children aged 6-59 months at the Sukarami Public Health Center in Palembang, because the prevalence of wasting is $5.4 \%$ and is considered a public health problem because still above $5 \%$.

\section{METHOD}

This research was an Observational, using a casecontrol research design. The place of research was conducted at the Sukarami Community Health Center, Sukabangun Subdistrict, voluntary district of Palembang with a sample of 60 toddlers. The subjects of this study were toddlers wasting randomly selected. After the data collected is done editing, coding, and entry in computer files. Data were then analyzed using the statistical test used in this bivariate analysis was the Chi-Squared test using a computerized SPSS program, which tested the significance of the relationship or difference with a $95 \%$ confidence level. (p-value $<0.05)$.

\section{RESULTS}

Table 1. Distribution of Toddlers by Background Characteristic

\begin{tabular}{lcc}
\hline Variables & Total & Percent \\
\hline Gender & 32 & \\
Male & 28 & 53.3 \\
Female & 2 & 46.7 \\
\hline Ages (Month) & 28 & 3.3 \\
-11 & 30 & 46.7 \\
$12-36$ & & 50 \\
$37-59$ & 24 & \\
\hline Parenting & 6 & 80 \\
Less & 28 & 20 \\
Good & 2 & 90.3 \\
Energy Intake & & 6.7 \\
Less & 21 & 70 \\
Good & 9 & 30 \\
\hline Protein Intake & & \\
Good & 28 & 90.3 \\
\hline Fat Intake & 2 & 6.7 \\
Less & & \\
Good & 26 & 16.7 \\
\hline Carbohiydrate Intake & 4 & 83.3 \\
Less & & \\
Good & 5 & \\
\hline Vitamin-A Intake & 25 & \\
Less & & \\
Good & & \\
\hline & & \\
\hline & & \\
\hline
\end{tabular}

Table 1 shows the proportion of sex toodlers suffering from male to be $53.3 \%$, 60 children under five in the case and control group were dominated by 37-59 months (50\%). it shows that parenting in the more or less category is found in the case group (80\%), and the control group (20\%), the average energy intake in the less category $(<80 \%$ RDA) is more found in the case group (90.3\%). Protein intake is in the poor category $(<80 \%$ RDA), more prevalent in the case group $(70 \%)$. Fat intake in the less category $(<80 \%$ RDA) was more in the case group (93.3\%). Carbohydrate intake in the low category $(<80 \% \mathrm{RDA})$ is more prevalent in the case group $(86.7 \%)$. Vitamin A intake was higher in the good category in the case group $(83.3 \%)$.

Table 2. Relationship between of Parenting, Macro Nutrition, Vitamin-A intake with Wasting Toddlers

\begin{tabular}{|c|c|c|c|}
\hline \multirow{2}{*}{ Variables } & \multicolumn{2}{|c|}{ Wasting Case } & \multirow[b]{2}{*}{$\begin{array}{c}P \\
\text { Value }\end{array}$} \\
\hline & $\begin{array}{c}\text { Case } \\
n(\%)\end{array}$ & $\begin{array}{c}\text { Control } \\
\text { n }(\%)\end{array}$ & \\
\hline \multicolumn{4}{|l|}{ Parenting } \\
\hline Less & $24(80)$ & $3(10)$ & \multirow{2}{*}{0.025} \\
\hline Good & $6(20)$ & $27(90)$ & \\
\hline \multicolumn{4}{|l|}{ Energy } \\
\hline Less & $28(90.3)$ & $3(10)$ & \multirow[t]{2}{*}{0.000} \\
\hline Good & $2(6.7)$ & $27(90)$ & \\
\hline \multicolumn{4}{|l|}{ Protein } \\
\hline Less & $21(70)$ & $28(90.3)$ & \multirow{2}{*}{0.026} \\
\hline Good & $9(30)$ & $2(6.7)$ & \\
\hline \multicolumn{4}{|l|}{ Fat Intake } \\
\hline Less & $28(90.3)$ & $5(16.7)$ & \multirow{2}{*}{0.007} \\
\hline Good & $2(6.7)$ & $25(83.3)$ & \\
\hline \multicolumn{4}{|l|}{ Carbohydrate } \\
\hline Less & $26(86.7)$ & $7(23.3)$ & \\
\hline Good & $4(13.3)$ & $23(76.7)$ & \\
\hline \multicolumn{4}{|l|}{ Vitamin-A } \\
\hline Less & $5(16.7)$ & $2(6.7)$ & \multirow{2}{*}{0.424} \\
\hline Good & $25(83.3)$ & $28(90.3)$ & \\
\hline
\end{tabular}

Table 2 shows that parenting in the less common category is found in the case group (80\%), the control group $(10 \%)$. This shows that the lower the parenting style, the more likely the occurrence of wasting. Based on the Chi-Square statistical test shows that the level of parenting given to toddlers is obtained $(p=0.025)$. Energy intake consumed by children under five obtained $(p=0,000)$. Protein intake consumed by infants obtained $(p=0.026)$. Fat intake of fat consumed by children under five obtained $(p=0.007)$. Carbohydrate intake consumed by children under five obtained $(\mathrm{p}=0.000)$.

Which means $\alpha<0.05$ that there is a significant relationship between Energi, Protein, Fat and Carbohiydrat intake with wasting in children aged 6-59 months in the working area of Sukarami Public Health Center in Palembang. Vitamin-A intake is in the good category in the case group $(83.3 \%)$, in the control group (93.3) This shows that vitamin A intake is less, the less likely the occurrence of wasting. Based on Chi-Square statistical tests showed that the intake of carbohydrates consumed by infants obtained a p- value of 0.424 which means $\alpha<0.05$, meaning that there is no significant relationship between vitamin- A intake and the incidence of wasting. 


\section{DISCUSSION}

The result showed that lower parenting style, the more likely the occurrence of wasting. The pattern of care for children under five in giving attention through food is very less found (80\%), which can cause toddlers to experience wasting. Ignorance of mothers about how to feed children can result in errors in the selection of food ingredients. The cause of wasting due to lack of energy intake, which in this study found under-fives in the category of less $(<80 \%$ RDA) found in the case group $(90.3 \%)$. The research result supported by previous studi which state that the pattern of care for children under five in giving attention through food is very less found $(80 \%)$, which can cause toddlers to experience wasting. Ignorance of mothers about how to feed children can result in errors in the selection of food ingredients. This will have an impact on the misuse of eating patterns so that children will cause thinness in children [7]. Another factor that plays a role in parenting is the work of parents. The data obtained shows that parents of toddlers have a variety of jobs and the most types of work as housewives and family heads as laborers. This is reinforced by the statement of Supartini saying that the work of parents is a source of income for families who can meet physical, psychological, and spiritual needs [8]. If parents have a jobthe established family welfare increases and the role in parenting are carried out well [9].

The recommended average energy requirement (RDA) for toddlers (6-59) months is $65-75 \mathrm{Kcal}$. The results of the study were energy intake $(243 \pm 1597.3)$ Kcal, with an average of $772 \mathrm{Kcal}$. Through interviews that show that in addition to eating patterns toddlers have not implemented a balanced nutritional menu. According to UNICEF, this is in accordance with the theory that energy intake as a macronutrient is a direct factor that influences nutritional status [10].

Protein intake for toddlers is a major factor contributing to a person's nutritional status. Based on interviews, it is known that eating children from protein sources such as nuts is still very less and the cost to fulfill animal protein is insufficient every day due to economic factors, so that most of the toddler's protein intake is in the less category $(<80 \%$ RDA) with protein intake $(7,5 \pm 48.2)$ grams, while the recommended protein requirements with RDA (12-35) grams/day or by $10-20 \%$ [11]. Protein is a source of energy and a source of builders. Protein will be converted into an energy source if energy from carbohydrates and fats is not sufficient for the body's needs. As a result, proteins cannot function as building blocks, so that toddler growth and development is inhibited. Toddlers need a protein intake of $10-20 \%$ [12].
Fats have an important role as a source of essential fatty acids needed for growth, as a source of highenergy energy and as a carrier of fat-soluble vitamins. The results of recall and interview found that most of the fat intake in the category of less $(<80 \%$ RDA) where the intake of fat received by toddlers as much (10.7 grams \pm 63 grams)/day, while the recommended fat requirements for toddlers (6-59) months is $15-20 \%$ around (34-62) grams/day. This shows the low intake of fat consumed by children, which causes wasted. Consumption of fat that has less impact on the nutritional state of children. Consuming less fat also disrupts the absorption of fat-soluble vitamins so that it will affect the metabolism in the body which will have an impact on nutritional status [13].

The recommended carbohydrate needs with the RDA of required toddlers with age (6-59) months Most of the carbohydrate intake in toddlers in the less category ( $<80 \% \mathrm{RDA})$ is $(86.7 \%)$. fat intake found (10.7 grams \pm 63 grams). The recommended fat requirement of $15-$ $20 \%$ for children under five (6-59) months around (3462) grams/day. This shows that the lower the intake of fat consumed, the greater the possibility of wasting. The lower the intake of carbohydrates consumed, the greater the possibility of wasting. Based on the results of interviews, it is known that wasting toddler food in the working area of the Sukarami Community Health Center from carbohydrate sources other than rice is still lacking, such as cassava, corn, potatoes, bread, and other types of wheat, thus affecting the results of analysts the amount of carbohydrate intake consumed. Carbohydrates are compounds combined from carbon, hydrogen and oxygen molecules. Carbohydrates are useful for producing energy for brain and body growth. Besides that, it helps metabolize fats and proteins [14].

The results of the analysis where the intake of vitamin A for toddlers obtained values with a value of (183.1 \pm 896) $\mathrm{mcg}$ with an average of $493 \mathrm{mcg} / \mathrm{day}$, where the intake of vitamin-A is sufficient for toddlers, so it has nothing to do with wasting. Through interviews with toddler respondents getting Vitamin A tablets twice a year, in the months (February and August), this adds to the contribution of vitamin-A to children under five. Because of vitamin-A status of children is influenced by several factors, not only from vitamin-A intake. Other factors that affect vitamin-A status include vitamin $\mathrm{A}$ reserves in the body that are stored in the liver [14]. [14]. Vitamin-A is an essential micronutrient against the body's defense against infection, development, and growth of children. Vitamin-A deficiency is associated with visual impairment, decreased growth and development weakened bone health and decreased general function 


\section{CONCLUSION}

The occurrence of wasting problems in children under five in the working area of the Sukarami Community Health Center in the Sukarami sub- district of Palembang's voluntary district was due to the lack of eating patterns $(p=0.025)$, energy $(p=0,000)$, protein $(\mathrm{p}=0.026)$, fat $(\mathrm{p}=0.007), \quad$ and carbohydrates $(\mathrm{p}=0,000)$ so that it causes wasting in toddlers.

\section{ACKNOWLEDGMENT}

The author is grateful to the Institute of Research Nutrition Department of Palembang Health Ministry of Health and the Sukarami Community Health Center.

\section{REFERENCES}

[1] Kemenkes RI. Keputusan Menteri Kesehatan RI Nomor: 1995/MENKES/SK/XII/2010 Tentang Standar Antropometri Penilaian Status Gizi Anak. Indonesia: http://gizi. depkes.go.id/wpcontent/uploads/2012/11/buku-sk antropometri-2010.pdf; 2011.

[2] Supariasa. Pendidikan dan Konsultasi Gizi. Jakarta: EGC; 2012.

[3] Pramudya AE, Bardosono S. Prevalensi Anak Beresiko Wasting dan Faktor-Faktor yang Berhubungan: Studi Cross Sectional Pada Anak Usia3-9 Tahun di Pesantren Tapak Sunan. Jakarta: Universitas IndonesiA; 2012.

[4] UNICEF. Malnutrion in Children 2017.

[5] Kemenkes RI. Hasil Pemantauan Status Gizi (PSG). Jakarta: Direktorat Gizi Masyarakat Direktorat Jendral Kesehatan Masyarakat Kemenkes; 2017.

[6] Dinkes Kota Palembang. Laporan Kegiatan Pemantauan Status Gizi Tahun 2017. Palembang: Dinas Kesehatan Palembang; 2017.

[7] Waliyo E, Marlenywati M, Nurseha N. Hubungan Pengetahuan Gizi dan Pola Pemberian Makanan Pendamping Asi Terhadap Status Gizi pada Umur 6-59 Bulan Di Wilayah Kerja Puskesmas Selalong Kecamatan Sekadau Hilir Kabupaten Sekadau. J Kedokt Dan Kesehat 2017;13:61. https://doi.org/10.24853/jkk.13.1.61-70.

[8] Supartini Y. Buku Ajar Konsep Dasar Keperawatan Anak. Jakarta: EGC; 2004.

[9] R. D. Membentuk Citra Diri yang Baik Melalui Pola Asuh dalam Membesarkan Anaka. Jakarta: Gramedia; 2009.

[10] Handayani. Nilai Anak dan Jajanan dalam Konteks Sosiokultural Studi Tentang Status Gizi Balita Pada Lingkungan Rentan Gizi di Desa Pecuk Kecamatan Mijen Kabupaten Demak Jawa Tengah. 2011.

[11] Kemenkes RI. Angka Kecukupan Gizi. 2013.

[12] Sutomo B, Anggraini Y. Menu Sehat Alami Untuk Batita dan Balita. Jakarta: DeMed; 2010.

[13] Soetjiningsih. Tumbuh Kembang Anak. Jakarta: EGC; 2014.

[14] Almatsier S. Prinsip Dasar Ilmu Gizi. Jakarta: Gramedia Pustaka Utama; 2011.

[15] Gropper. Advance Nutrition and Human Metabolism. Canada: Wordworth Cengage Learning; 2009. 